ting up new, or developing existing, industries, having regard to the financial facilities necessary for success.

The Committee recognises that many engineering firms in this country are threatened with serious financial trouble from the difficulty of raising new capital, and the pressure of the munitions levy and the excess profits taxation. It finds that in some branches the industry has not kept pace with the demands of customers, and that users have been driven to purchase more up-to-date machinery in foreign markets. The principal remedies for this appear to be more specialisation and standardisation in the production of individual firms. Both tend to facilitate manufacture in quantities and so reduce cost. The Committee also emphasises the importance of scientific and industrial research, and regards with satisfaction the formation of associations in some trades for that purpose, assisted by grants from the Department of Scientific and Industrial Research.

Over much of the field surveyed, the resources for production in this country appear to be adequate. But there are cases where articles which could well be manufactured here were, before the war, obtained wholly or in great part from abroad. To take a few examples. Milk-testing appliances were obtained exclusively from Switzerland. Germany had captured most of the trade in whitemetal spoons and forks. Lathe and drill chucks, gear-cutting machines, and mechanics' fine tools were, to a large extent, imported from America and Germany. Precision measuring instruments were not adequately made in this country. Electrical insulating materials were, to a great extent, if not wholly, imported from abroad, and, although progress has been made in overcoming the deficiency during the war, the opinion of the industry is that much research work is necessary, and that for success the manufacture must receive State assistance.

The market for tool-room and precision lathes has been almost entirely in the hands of foreign manufacturers, and that for the remarkable class of watchmakers' lathes, with hundreds of interchangeable fittings, is wholly in the hands of German firms.

Some branches of industry, especially the electrical industry, complain of the effect of unrestricted imports. It is pointed out that the insecurity of the home market, due to the fact that foreign products can be introduced and sold at an unreasonable price, discourages the investment of capital, and seriously hampers the development of home manufacture. Foreign makers of electrical plant, protected in their home markets by tariffs, produce on a larger scale and lower cost than the British manufacturer; in face of such conditions the industry cannot be expected to thrive. Magnetos before the war were entirely produced in Germany. During the war they have been quite successfully made here. But the exclusion of German magnetos is demanded for a period after the war except under licence and with No. $258 \mathrm{I}$, VOL. IO3] a duty on import. Protection or Government support is asked for in many cases. No doubt there are industries so important and so valuable as a means of training skilled workers that a claim of this kind is justified. The clock and watch manufacture seems to be such a case. But such claims must be carefully considered, in view of the fact that it is one of the objects of the Peace Conference to remove, so far as possible, all economic barriers.

It is clear from the report of the Sub-Committee dealing with scientific apparatus that the country has been backward in developing this vital industry, affecting research, education, and many other industries. The Committee recommends that for ten years scientific apparatus should not be imported except under licence, which should be granted and continued only so long as British apparatus is not available at reasonable prices. The following list gives some of the cases examined by the Sub-Committee: Balances and barometers largely obtained from Germany and sold under the names of English dealers; photographic apparatus supplied in large numbers by Germany and the United States; dividing engines supplied chiefly by Switzerland; drawing instruments derived chiefly from Germany; micrometers and measuring instruments largely supplied by the U.S.A. ; physical apparatus obtained from Germany and sold under the names of English dealers; photographic lenses, which formerly came from Germany and France, might be manufactured here; also microscopes supplied largely from Germany.

It is stated that there are classes of articles imported which are made in such large quantities, and have such manufacturing and inventive resources behind them, as to make competition extremely difficult. In such cases, if the manufacture is to be developed in this country, it appears to be necessary that State assistance should be given towards overcoming the difficulty of competition. It is also recommended that Government Departments and public authorities should make it a practice to place orders for standard goods of British manufacture, and also have in view the desirability of encouraging the production of articles of new and improved types.

\section{DR. HENRY WILDE, F.R.S.}

$\mathrm{D}^{\mathrm{R}}$ . HENRY WILDE, whose death was announced in NATURE of April 3, was a man of remarkable individuality and a pioneer in electrical engineering. He was born in Manchester in I833. During his apprenticeship he experimented with voltaic cells, electrical machines, electrical kites, and the electro-deposition of metals. He soon realised the great commercial possibilities of the applications of electricity, and he decided, when he was twenty-three years of age, to commence in business as a telegraph engineer and lightning-conductor expert. Several years were devoted to the invention of a magneto-electric alphabetic telegraph. Experiments with elec- 
tro-magnets led to the design of an improved electric generator described in his patents of $x 863$ and $186_{5}$. Wilde's "dynamo-electric machines" -as they were named by Charles Brooke, F.R.S. - quickly replaced batteries for electro-deposition :nd arc 'ighting, but in use they had the serious disar.vantage of becoming very hot. In the encicavour to 'ure this fault Wilde designed a very different tae of dynamo. This was a multipolar machile, with sixteen pairs of electro-magnets, which was made self-exciting by a' "minor" current from four of the armature bobbins. Both this and the earlier machine were used by Elkington for the electrolytic refining of copper.

Wilde directed lis attention to the use of his generats:s for other electro-chemical purposes. He obtained a patent in 187 I for protecting iron tubes from corrosion by coating them with copper, and four years late: he introduced a valuable process for making by electro-deposition rollers of copper used in calico printing. With a revolving cathocle he was enabled to employ relatively high current densities, and yet obtain a good quality of copper. 'This invention proved to be financially the most valuable of all his patents.

Experiments with two of the multipolar machines led to the discovery in 1868 that it was possible to run them, when in synchronism, as alternators in parallel. The importance of this was not realised until fifteen years later, when Dr. John Hopkinson, unaware of the work of Wilde, showed that this was theoretically possible, and now the parallel running of alternators is an everyday occurrence at supply stations.

Wilde designed direct- and alternating-current arc lamps suitable for search- and light-house purposes. Some large battleships were equipped with these under his direction, and after the Titanic disaster he strongly urged that mercantile vessels should be fitted with searchlights.

In 1884 Wilde retired from his business as an electrical engineer. During the remainder of his long life he chiefly devoted himself to special scientific subjects. He published a number of papers relating to atomic weights, and invented a magnetarium for reproducing the phenomena of terrestrial magnetism.

Wilde was a considerable benefactor to public institutions, amongst which must be especially mentioned the Literary and Philosophical Society of Manchester. Including the Wilde endowment, his contributions to the society exceeded ro,oool. He died at The Hurst, Alderley Edge, Cheshire, where his wife also died twenty-six years previously. He had no children. After some legacies, the residue of his estate has been bequeathed to the University of Oxford.

W. W. H. G.

\section{NOTES.}

THE projected Atlantic flight is naturally exciting considerable interest at present, but it has recently been bad flying. weather, and large storm systems have been sweeping eastivards across the ocean. For the flight to be safe and successful such disturbances must be avoided. In a statement issued on Monday NO. $258 \mathrm{I}$, VOL. IO3] by the Air Ministry relative to the weather factor of the flight, estimates were given of the time required for the flight eastwards and westwards between Newfoundland and Ireland under favourable and adverse conditions during the months of April, May, and June. The report states "that in every case weather conditions are more favourable for flying from Newfoundland to Ireland than from east to west, and that it would on certain occasions be impossible to accomplish the journey in the latter direction." It is not easy to see how the Air Minstry has used the avail. able data, and there must necessarily be a great element of doubt meteorologically. The aeroplane flying eastwards will travel about four times as fast as the average easterly translation of an Atlantic storm, and may quite easily overtake at least one storm. A storm. on an average, takes four or five days in crossing the Atlantic from shore to shore; it may, however, be developed in mid-ocean and start its passage eastwards, and when nearing the European side the track of the storm may quite possibly be to the northward. The upper air generally has a quick movement to the eastward. So far as possible, for a successful air passage choice should be made of a period when the Atlantic is comparatively free from important storm areas; such periods exist, but under the present conditions indefinite waiting has its drawbacks. Meteorologists can scarcely favour an attempt to fly westwards until further experience is gained of the movements of the upper air.

Wireless telephony is being installed in the Folkestone-Cologne aerial mail service. Along this route a chain of call-stations is being erected, and the aeroplanes encaged in the service are being fitted with both sending and receiving sets. In practical tests it was found that clear voice signals were transmitted from 'plane to ground, and vice versa, at a distance of thirty miles. By operating a simple switch the connections are changed from "send" to "receive." A certain amount of voice-training is desirable, otherwise the voice may be drowned by the engine drone. The operator in the aeroplane wears a carefully fitted helmet with ear-receivers. It is necessary that complete freedom of movement should be ensured and all wind-noises eliminated. At present specially trained men are employed to fit on the helmets. Improvements are continually being effected in the methods and anparatus, so that the complete practical transmission of speech between aeroplanes and ground stations is assured.

No profession is free from its obscurantists, and the little band of half a dozen medical men who serve the anti-vivisectionist agitation have once again written to the Times to declare their conviction that experiments on dogs are unnecessary for the advance of medical science. Such a letter, devoid as it is of authority, serves a useful purpose in emphasising the weighty character of the resolution recently passed at the meeting of the British Medical Association, when the combined sections of medicine, pathologv, and preventive medicine expressed their opinion, without a single dissentient, that the prohibition of experiments upon dogs would hamper the progress of medicine, and render Britain alone among civilised nations unable to contribute to progress in a department of medical research in which it has hitherto played a distinguished part. The Royal College of Physicians has also recorded its opinion "that the passing into law of the Dogs Protection Bill, now before the House of Commons, will greatly retard the progress of our knowledge with regard to the prevention and treatment of disease." The supporters of the Bill, to judge from their letters in the Press, are annoyed at the statement made by men who actually carry out 